\title{
Role of Village-Owned Enterprises in Farming Community Empowerment
}

\author{
Muhammad Rais Rahmat Razak ${ }^{1}$ and Sofyan B ${ }^{2,3}$ \\ ${ }^{1}$ Universitas Muhammadiyah Sidenreng Rappang Government Science \& Candidates in \\ Public Administration Doctoral Program Makassar State University. \\ ${ }^{2}$ Department of Public Administration, Universitas Muhammadiyah Sidenreng Rappang \\ ${ }^{3}$ Doctoral Program in Public Administration, Hasanuddin University, Makassar.
}

Email:mraisrahmat@umsrappang.ac.id

\begin{abstract}
The empowered community is a strong capital in developing the national economy; the government, as the manager of the State, should maximize the village-owned enterprises (called Bumdes), especially the farming community in the villages. This paper aims to find out the role of the Bumdes in empowering the farming community. The results showed that the role of Bumdes was not good enough and had a direct influence on the weakness of community empowerment activities in the village
\end{abstract}

Keywords: Bumdes, empowerment, farming community, role

\section{Introduction}

Building the national economy of the village, as stated in the administration of President Jokowi, needs to be maximized by empowering economic institutions formed by the community, especially farmers, together with the village government. Increasing the budget allocation for the state expenditure in the village fund program to 1 billion per village in 2020 will be a golden opportunity for Bumdes to create innovative and productive activities. Establishment of Bumdes in villages is one form of implementation of the Law of the Republic of Indonesia Number 6 of 2014 concerning villages that are followed up with Government Regulation Number 43 of 2014. The potential number of residents who are mostly farmers and the availability of natural resources in the village, if managed properly, will provide welfare for the community. But it is realized or not during this development at the village level still has many weaknesses. As is the case with the quality of human resources and organizational management. Various efforts have been made by the government by launching development activities and village development programs, one of which is through the Village-Owned Enterprises (Bumdes). According to Minister of Home Affairs Regulation No. 39/2010, Bumdes is a village business formed and established by the village government in which capital ownership and management are carried out by the village government and the community. The existence of Bumdes was also strengthened in Article 87-90 of Law 6/2014, stating that the establishment of Bumdes was agreed upon through village meetings and managed with a family and mutual cooperation spirit. So it can be said Bumdes has a social function that is contributing as a social service provider and a commercial function that is, Bumdes aims to make a profit through offering local resources (goods and services) to the market [1]. For this reason, the government needs to know the role and performance of Bumdes in the village so that a general understanding is obtained to improve the management of Bumdes, who are mostly farmers in each village.

Previous research stated that in 2006 in Bojonegoro District 419, Bumdes had been established. The results of the mapping carried out by the Community Empowerment Agency and the Village Government in 2013 stated that the number of active Bumdes 
was only 21. In his research, it was found that Bumdes were considered successful; in fact, they had not been able to contribute to village cash income or original village income [2]. Another study in Landungsari Village, Dau Subdistrict, Malang Regency, concluded that only a portion of the community in Landungsari Village felt helped by the existence of Bumdes, namely through the leasing market stalls and borrowing capital. However, as a whole has not been able to meet the needs of the community and contribute to increasing village income [3], this study aims to determine the extent of the role of Bumdes in Sipodeceng village and how the conditions of community empowerment and, finally, to find out how the role of Bumdes in empowering the farming community.

\section{Method}

The research method used is a quantitative method by describing the variables and problem formulation that will be used. As an initial step in designing research that is a plan or strategy used to answer research problems and controlling variables or research focus, it can also be understood as a plan and structure of inquiry that is used to obtain empirical evidence in answering research questions [4]. This research takes loci Bumdes Padaidi in Sipodeceng Village. This research is included in institutional research, which will get information and can be useful in developing institutional-level explanations, which according to David Kline, is intended to explain the position of the variables studied and the relationship between the two or between one variable with another variable. [5] The formulation of the problem in this study consisted of two descriptive or independent formulations, namely the role of the Bumdes Padaidi Sipodeceng and community empowerment in Sipodeceng Village. As well as being supplemented by the formulation of associative issues, namely How is the role of Bumdes Padaidi in Farming community empowerment activities in Sipodeceng Village. As an initial hypothesis, the role of Bumdes Padaidi is influential in increasing farming community empowerment in Sipodeceng Village. The population used is all individuals/units that are the target of the study, while the sample is part of the population selected following certain procedures so that it can represent the population. The total population used is 1200 households. Then the determination of the sample using the formula Slovin, namely $\mathrm{N} /(\mathrm{Ne} 2+1)$ and obtained a total sample of 93 people. [6]. To maintain data quality, a validity test is performed to ascertain whether the data from the field is valid data, and nothing is missing. With the testing approach "Product Moment Pearson Correlation" and the help of SPSS version 20.00 each item questionnaire questions will be tested for validity by comparing the $r$ count with the $r$ table. If $r$ count is greater than $r$ table, then the data is considered valid. Furthermore, valid data are tested for reliability by comparing alpha Cronbach with $r$ table. If Cronbach's alpha is greater than $r$ table, then valid data is considered reliable. Data is processed into a frequency table with a Likert scale to provide a score on the results of the study. The results of the frequency table management will give a description of the condition of two descriptive problem formulations, namely the role of Bumdes Padaidi and community empowerment. Meanwhile, to find out the associative problem formulation or whether there is a relationship between the variables "X" and "Y", it can be used Simple Linear Regression Analysis using SPSS version 20.00. So the results of the analysis of this data are expected to be able to answer the three problem statements that lie ahead.

\section{The Role of Bumdes and Community Empowerment}

\subsection{The Role of Bumdes}

In a large Indonesian dictionary, a role is an action carried out by a person or group of people in an event or part that someone plays in an event. The role is a dynamic aspect, 
and if a person carries out his rights and obligations according to his position, then he plays a role. The difference between position and role is in the interest of science. The two cannot be separated because one depends on the other, and vice versa. While other experts such as Gros, quoted in the book "Points of Mind in Sociology" by David Berry, explain the role is a set of expectations imposed on individuals or groups who occupy certain social positions. The importance of the role is because it regulates the behavior of a person or people's economic institutions such as the Bumdes [7][8]. So the role shows how a person or institution benefits others.

\subsection{Bumdes Management}

Bumdes is a village business formed and established by the village government with capital ownership and its management carried out by the village government and the community. The four main objectives of establishing the Bumdes are: Improving the economy, increasing the village's original income, increasing the processing of the village's potential according to community needs, becoming the backbone of growth and equitable distribution of the village economy [9]. These four objectives will be used as indicators in observing the role of the Bumdes in the community. Institutions formed by the community are expected to contribute to efforts to improve the economy. Bumdes, as an organization or economic institution in its operations, can practice the basic principles of management so that it can be managed professionally [10].

\subsection{Community empowerment}

Conceptually, empowerment, or empowerment comes from the word power (power or empowerment). The main idea of empowerment is in contact with the ability to make others do what we want and to be free of their desires and interests. Empowerment focuses on power and is substantially a process of breaking down the relationship between subject and object. This process prioritizes the subject's recognition of the ability or power possessed by the object. Broadly speaking, this process sees the importance of flowing power from the subject to the object. The final result of empowerment is the shifting of individual functions from the original object to a new subject so that social relations will only be characterized by social relations between subjects and other subjects [11]. Community empowerment is the power, strength, or ability of the community to identify potentials and problems and can determine alternative solutions independently. Community empowerment is measured through three aspects, namely: ability in decision making, independence, and ability to take advantage of business for the future [12]. Indicators of empowerment refer to the process of development, psychological conditions that are characterized by self-confidence, liberation resulting from a social movement [13]. In this paper, five indicators are used namely; first the ability to prepare and use existing resources in the community, the second can run "bottom-up planning", then the ability and economic activity, the ability to prepare the family's future and finally the ability to express opinions and aspirations without pressure [14]. Therefore, empowered communities will be able and strong to participate in the development, able to oversee the course of development, and also enjoy the results of development [15].

\section{Data Analysis}

\subsection{Characteristics of Respondents}

4.1.1. Gender and age: Of the 93 respondents surveyed consisted of 46 male or $49.5 \%$ male and 47 female or $50.5 \%$ female, and characteristics based on age.

Table 1. Base on Age 


\begin{tabular}{|c|c|c|c|}
\hline No & Age & Frequency & Percentage \\
\hline 1 & $17-26$ years & 17 & $18.3 \%$ \\
\hline 2 & $27-36$ years & 17 & $18.3 \%$ \\
\hline 3 & $37-46$ years & 30 & $32.3 \%$ \\
\hline 4 & $47-56$ years & 25 & $26.9 \%$ \\
\hline 5 & $57-66$ years & 4 & $4.3 \%$ \\
\hline & Total & 93 & $100 \%$ \\
\hline
\end{tabular}

4.1.2. Occupation: Based on work dominated by household affairs, 35 people $38 \%$ then self-employed 27 people, $29 \%$ and farmers 19 people or $20 \%$.

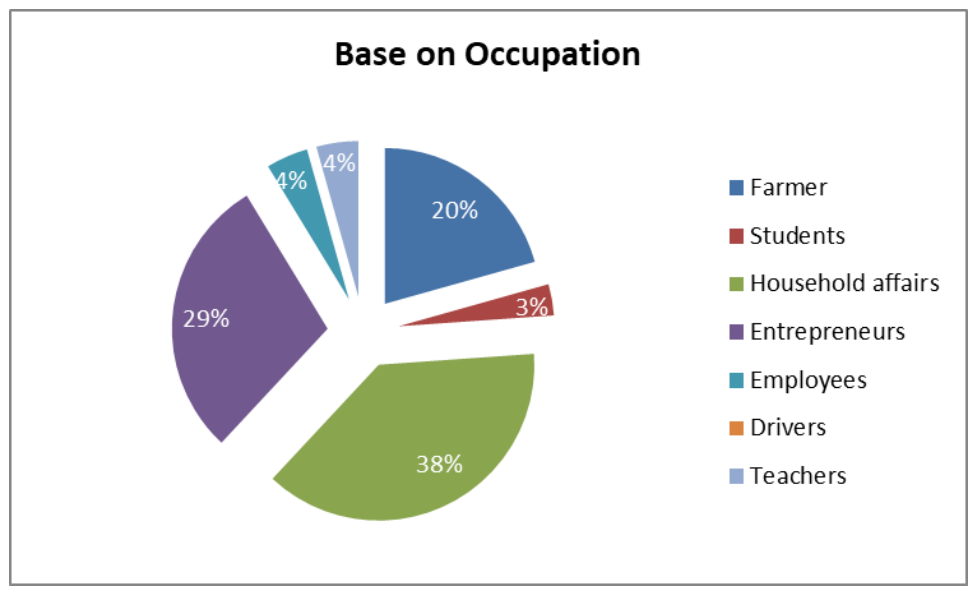

Figure 1. Base On Occupation

\subsubsection{Last education}

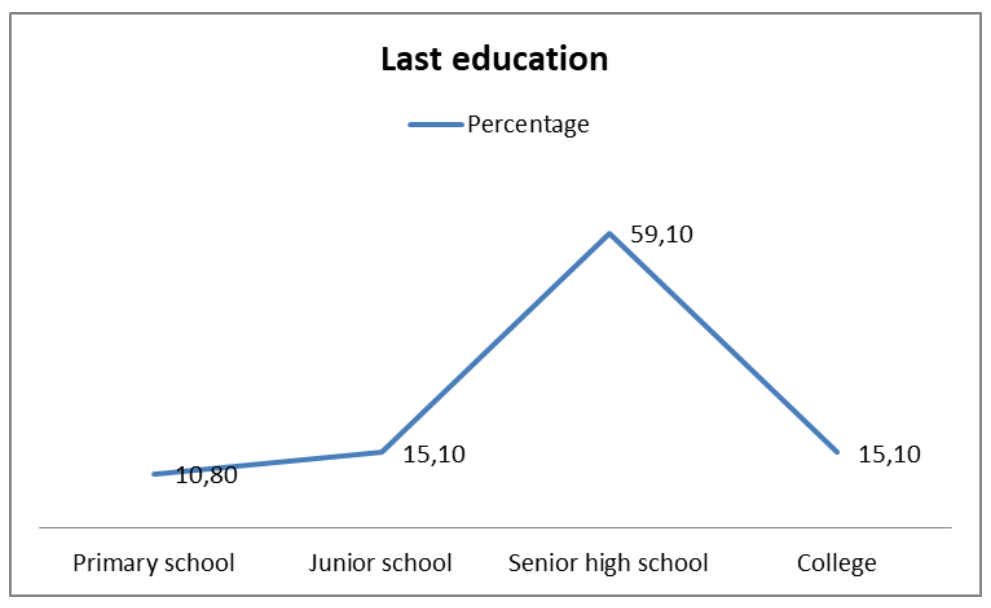

Figure 2. Last Education

4.2. Frequency table analysis. The formula used to analyze data using frequency tabulation techniques, namely: 
$\mathrm{P}=\frac{\mathrm{F}}{\mathrm{n}} \times 100 \%$

Information:

$\mathrm{P}=$ Percentage Results

$\mathrm{F}=$ Number of Frequency of Respondents

$\mathrm{n}=$ Number of Samples

To describe the percentage classification of the calculation results has been processed, which is processed as in the table below:

Table 2. Research Results Categories

\begin{tabular}{|l|c|}
\hline \multicolumn{1}{|c|}{ Category type } & Range (\%) \\
\hline Very good & $81-100$ \\
\hline Good & $61-80$ \\
\hline Poor & $41-60$ \\
\hline Bad & $21-40$ \\
\hline is not very good & $0-20$ \\
\hline
\end{tabular}

\subsection{Data Quality test}

4.3.1. Validity: Validity analysis is carried out on variables, Role of Bumdes $(X)$ and Community Empowerment (Y), by using, "product moment Pearson correlation" that is, comparing correlation values (r) with (r) tables on degrees of freedom (df), 91 with a significance of 0.05), the value obtained, ( $\mathrm{r}$ ) table is 0.1716. Recapitulation of the calculated value (r) on the variables $\mathrm{X}$ and $\mathrm{Y}$ obtained correlation values (r) more than $(r)$ tables. Then the validity test results show that nine items in the " $\mathrm{X}$ " variable and ten items in the "Y" variable are valid.

4.3.2. Reliability Test: Reliability testing is carried out using the "product moment Pearson correlation" approach. The test results show that the question items used in the role of Bumdes and Community Empowerment can be declared reliable because they have a Cronbach alpha value on the variables $\mathrm{x}$ and $\mathrm{Y}$ greater than $\mathrm{r}$ table 0.1716 . This shows that the data used in this study are valid and reliable.

\section{Results and Discussion}

\subsection{The Role of Sipodeceng Village Bumdes (variable " $X ")$}

To analyze the $\mathrm{X}$ variable, which is the role of Bumdes, is done by analyzing the frequency table by scoring data using a Likert scale. Then the data recapitulation of each indicator is obtained as follows.

Table 3. Recapitulation of Bumdes (X) role variables

\begin{tabular}{|c|l|c|}
\hline No. & \multicolumn{1}{|c|}{ Indicator } & Percentage (\%) \\
\hline 1 & increasing the village economy & 58.39 \\
\hline 2 & increasing original village income & 55.59 \\
\hline 3 & $\begin{array}{l}\text { increase management of village potential } \\
\text { according to community needs }\end{array}$ & 52.9 \\
\hline 4 & backs growth and economic equality & 49.9 \\
\hline
\end{tabular}


Average Percentage (\%)

54.19

Bumdes role variable has an average classification category of 54.19 percent or is in the unfavorable category [12]. This happened according to Gimran who also served as Chair of the Bumdes at the time of the interview on 1 August 2019 due to;

"The existing Bumdes is not yet active, and there is no fund for Bumdes management from the village government, so the village business entity has not given many roles to the community".

In line with the results of previous research, it is stated that the role of Bumdes in businesses that have not yet received funding has not yet played a role, in fact, there are some businesses such as rubber that have received financial assistance and have not yet played a role in the economy [4]. This also happens to Bumdes that have been researched by other studies and states that the role of Bumdes in improving the village economy should begin with improvements to the proper legality so that the BUMDes really prove its role as an effort in increasing the Village's Original Income (abbreviated with PAD ) and grow the whole and complete village economy [15].

\subsection{Community empowerment (variable "Y")}

The results of data analysis on variable $\mathrm{Y}$, namely community empowerment using frequency tables and Likert scale. then the recapitulation of the values of each indicator is obtained as follows

Table 4. Recapitulation of community empowerment (Y)

\begin{tabular}{|c|l|c|}
\hline No. & \multicolumn{1}{|c|}{ Indicator } & Percentage (\%) \\
\hline 1 & Ability to prepare and use community resources & 47.53 \\
\hline 2 & Bottom-up planning & 52.8 \\
\hline 3 & Economic capabilities and activities & 46.77 \\
\hline 4 & Ability to prepare a family future & 50.54 \\
\hline 5 & The ability to express opinions & 48.92 \\
\hline \multicolumn{2}{|l|}{ Average Percentage (\%) } & 49.32 \\
\hline
\end{tabular}

Recapitulation of community empowerment variables has an average value of the category classification of 49.32 percent or is in the unfavorable category. This happened according to Gimran due to;

"Most people are still dependent on government programs, and they are still difficult to take the initiative, also probably because most of them are farmers".

\subsection{Simple Linear Regression Analysis}

To answer the formulation of associative problems, namely how the correlation or relationship between the role of Bumdes Desa Sipodeceng in community empowerment, can use simple linear regression analysis with the following general equations::

$\mathrm{Y}=\mathrm{bo}+\mathrm{b} \cdot \mathrm{X}$

Where:

$\mathrm{Y}$, is a variable of community empowerment

bo, constant 
$\mathrm{b}$, is the regression coefficient

$\mathrm{X}$, is the role variable of the Sipodeceng Village Bumdes.

The " $b$ " coefficient is called the regression direction coefficient and represents the average change in the " $\mathrm{Y}$ " variable for each change in the " $\mathrm{X}$ " variable by one unit. This change is an increase if the value of " $b$ " is positive and is a decrease if the value becomes "b" negative. By using spss data processing version 20.00, in simple linear regression analysis, the output data written in the coefficient table is obtained as follows, Constanta is 7.446 and the regression coefficient (b) 0.791 then by entering these numbers in the simple regression equation is obtained as follows:

$$
\mathrm{Y}=7.446+0.791 \mathrm{X}
$$

This shows that, if the role of Bumdes $(\mathrm{X})$ is non-existent or zero, then the value of community empowerment will remain at 7.446. The regression coefficient $\mathrm{X}$ of 0.791 states that for each addition of one unit of Bumdes $(\mathrm{X})$ role value, the value of community empowerment will also increase by 0.791 .

To test the hypothesis, the values obtained from the coefficient table are t count 4.244, and the significance value is 0.00 . They are so based on the criteria if $t$ count $>t$ table and significance $<0.05$, then the Hypothesis (H0) is rejected, and the working hypothesis ( $\mathrm{Ha}$ ) is accepted. The results of data analysis showed that the value of t count (4.244) $>t$ table (1.986) with a significance of $0.000<0.05$. This shows that Ho was rejected and Ha was accepted, so it can be concluded that the role of Bumdes (X) influences the community empowerment variable (Y).

To find out how much influence the role of the Bumdes (X) variable on the community empowerment variable $(\mathrm{Y})$, it can be seen how much value $(\mathrm{r} 2)$ or $\mathrm{r}$ square in the model summary table. R-square value of 0.528 indicates that the role variable of Bumdes (X) has a $52.8 \%$ influence on community empowerment, while $47.2 \%$ is influenced by other factors not examined. The findings in this study indicate that the role of the Bumdes in community empowerment exists and requires special attention or policy from the village government. If Bumdes is well managed and its role will be enhanced, it will directly affect community empowerment. The results of the interview with Mr. Gimran (Head of Sipodeceng BumDes) on Thursday, August 1, 2019, stated that:

"Actually, Bumdes has never been active for several reasons, one of them is because there is no funds to manage the Bumdes, besides that the Bumdes management also never holds meetings during the formation of the Bumdes, although for the time being the Bumdes has not been active but from the village, side has proposed a budget for bumdes, so we have planned the future bumdes will continue ".

In line with the results of previous studies in the Cokrokembang village, Bumdes in the village can still run in one business sector, namely savings and loans. And actually, there is some potential that can be developed by looking at the diversity of existing businesses, but the problem is that business people still don't understand the benefits of being a Bumdes member, so they choose to market their business independently. In addition, inadequate human resources and lack of management awareness to maintain and develop Bumdes [16]. The conditions are almost the same in Sipodeceng Village. Researchers can conclude that Bumdes Padaidi is similar to conditions in Cokrokembang Village. Where the presence of Bumdes has not been put to good use, it has been proven that in 2018 the establishment of the S24 Sipodeceng mart was initiated by students of the Field Work Plus Lecture (called KKLP) from the Department of Social Sciences Muhammadiyah Rappang, but until now business has been ignored, and it is unclear how it will proceed. 


\section{Conclusion}

The role of Bumdes includes; improving the village economy, original village income, managing village potential in accordance with community needs, economic growth, and equity has an average value of 54.19 percent included in the category of less role. This shows that the Bumdes need to empower the farming community in order to improve the economy of Sipodeceng Village. The conditions of community empowerment, which are mostly farmers in Sipodeceng village, include; the ability to use resources in the community, bottom-up planning, the ability of economic activities, the ability to prepare for the future and the ability to express opinions have an average value of 49.32 percent included in the category of powerlessness. This shows that the Sipodeceng village community in this study was still not empowered. The role of Bumdes "Padaidi" in empowering the community of Desa Sipodeceng has an influence based on the results of the summary table 52.8, including tends to strengthen and if the role of Bumdes increases, the community will be more empowered.

\section{References}

[1] A. S. Wijanarko, "Peran Badan Usaha Milik Desa (Bumdes) dalam Pemberdayaan Masyarakat di Desa Pandankrajan Kecamatan Kemlagi Kabupaten Mojokerto,” Universitas Pembangunan Nasional Veteran Jawa Timur, (2012).

[2] P. Budiono, "Implementasi Kebijakan Badan Usaha Milik Desa ( Bumdes ) Di Bojonegoro ( Studi di Desa Ngringinrejo Kecamatan Kalitidu Dan Desa Kedungprimpen Kecamatan Kanor )," J. Polit. Muda, vol. 4, no. 1,(2015), pp. 116-125.

[3] R. A. Prasetyo, "Peranan Bumdes dalam pembangunan dan pemberdayaan Masyarakat di Desa Pejambon Kec. Sumberrejo Kab Bojonegoro,” J. Dialekt., vol. 11 no 1, (2016), pp. 86-100.

[4] J. Ahmad, "Metode Penelitian Administrasi Publik Teori dan Aplikasi", May. Gava Media, (2015).

[5] Sugiyono, "MetodePenelitian Administrasi. Publik", CV. Alfabeta, Bandung, (2017).

[6] Purwanto, "Metode Penelitian Kuantitatif Untuk Administrasi Publik dan masalah-masalah Sosial", Gava Media, (2017)

[7] A. Rahman, "Peranan Bumdes-Kajian Teori."

[8] S. Razak, M.R.R.R. Harfiah, "Partisipasi Masyarakat di Daerah Pegunungan terhadap Perwujudan Good Governance," Akmen J. Ilm., vol. 15, no. 3, (2018), pp. 476-486.

[9] D. L. Jumono, "Bumdes-Kajian Teori," UNILA, (2013).

[10] R. G. Terry, "Dasar-dasar Manajemen", PT. Bumi Aksara, Jakarta, (2013).

[11] H. M. A Azis, "Dakwah Pemberdayaan Masyarakat" , PT LKiS Pelangi Aksara, Surabaya, (2005).

[12] K. (Dikti) Widjajanti, "Model Pemberdayaan Masyarakat," Ekon. Pembang., vol. 12, no. 1, (2011), pp. $15-27$.

[13] E. Suharto, "Membangun Masyarakat Memberdayakan Rakyat Kajian Strategis Pembangunan Kesejahteraan Sosial dan Pekerjaan Sosial", PT. Refika Aditama, Bandung, (2005).

[14] S. N. Y. Haqqie, "Partisipasi Masyarakat dalam Program Pemberdayaan (Studi Kasus Kegiatan Pembuatan Pupuk Organic di Desa Blagung, Boyolali )," Universitas Negeri Semarang, (2016).

[15] M. R. . Razak, M. Dahong, J. Ahmad, H. Dema, and A. Mustanir, "The Effect of Siri 's Marriage on Government Administration International Journal of Sciences: The Effect of Siri's Marriage on Government Administration,” Int. J. Sci. Basic Appl. Res., vol. 42, no. 3, (2009), pp. 171-184.

[16] D. Rahmadanik, "Peran Bumdes Dalam Pemberdayaan Masyarakat Desa Cokrokembang Kecamatan Ngadirojo Kabupaten Pacitan,” JPAP J. Penelit. Adm. Publik, vol. 4, no. 1, (2018), pp. 909-913. 